\title{
Towards a Service-Led Relationship in Project-Based Firms
}

To cite this article: Kamran Razmdoost \& Grant Mills (2016): Towards a serviceled relationship in project-based firms, Construction Management and Economics, DOI:10.1080/01446193.2016.1200106.

\begin{abstract}
Project-based firms increasingly apply practices that are in line with relationship marketing (RM), which is a shift from individuality to mutuality, and servicedominant logic (SDL), which is a shift from a focus on goods exchange to an emphasis on service exchange. These firms also adopt value co-creation processes, benefiting from both RM and SDL views. However, their overall transition towards $\mathrm{RM}$, SDL and/or both is not clearly understood. Therefore, the research aim is to explain how and why project-based firms have moved away from transitional marketing. A retrospective action research between 2002 and 2009 provides process data on how a single main contractor adapted their marketing approach over five publicly funded projects within the oil, gas and petrochemical industries. The findings show that the uniqueness and dynamics of projects necessitate the adoption of both SDL and RM, entitled the service-led relationship here. This transition occurs through services expansion, multi-level distributed interactions and process-oriented performance management in projects. The firm enabled the transition through the evolution of both institutional mechanisms such as contracts and organisational structure, and people attributes such as capabilities and culture.
\end{abstract}

\section{Keywords}

Relationship marketing, service-dominant logic, service-led relationship, interaction, project-based firm 


\section{Introduction}

Relationship marketing (RM) and service-dominant logic (SDL) have advanced knowledge and practice from those which are traditionally transaction-oriented. However, existing investigations of these two theories do not explore the rationale and processes through which firms, particularly project-based firms, have moved from a more transactional approach. Building on RM and SDL, the evolution of one project-based firm is used to describe why and how it moved from transactional marketing.

RM encourages firms to increase their profitability by building long-term relationships with profitable customers, rather than focusing on single exchange (Berry, 1995). The main goal of RM is to maximise the lifetime value of a customer (Christopher et al., 2002) through the maintenance of customer satisfaction (Grönroos, 1994). In fact, in RM providers and customers maximise the value created for both sides of the exchange through a strong relationship (Sheth and Parvatiyar, 1995).

The creation and maintenance of high quality relationships by project-based firms, such as those in construction, have been advantageous in practice (Jin et al., 2007; Kadefors, 2004; Skaates et al., 2002). What is more, mechanisms such as key account management and relational contracting have shown to increase long-term profitability (Smyth and Fitch, 2009). However, the theoretical conception and evolution of RM has not been documented within a project-based firm.

SDL has shifted the focus of exchanges by suggesting service as the unit of exchange (Vargo and Lusch, 2004). In this view, service is the application of resources for the benefit of another party and value is always determined by the beneficiary (Vargo 
and Lusch, 2008). Service here is different from services as a term for non-goods products (Gummesson, 2007). Furthermore, a project is a temporary organization of resources aiming to achieve a specific goal (Turner and Müller, 2003). It is "a unique endeavour - in the sense of a one-off - undertaken to accomplish a defined objective" (Morris, 2002, 83) and so uniqueness is the main characteristic of projects (Morris, 2002), which leads to uncertainty and transience (Turner and Müller, 2003). Therefore, a project is viewed as a unique service that is exchanged between a provider and a customer.

The combination of RM and SDL has been investigated previously in project-based and construction firms to explain the value co-creation (or co-production) process (e.g., Hsu et al., 2013; Jacobsson and Roth, 2014; Sivunen et al., 2013). There have been attempts to explain the relationship between SDL and RM in routine service exchanges (e.g., Vargo and Lusch, 2010; Gummesson and Mele, 2010). This has also been in the interest of project and construction management researchers, as Jacobsson and Roth (2014) asked for further research to investigate the purpose of partnering and the role of relationships in value co-creation. Indeed, little is known about why and how project-based firms move towards SDL and RM because longitudinal research is seldom done to illustrate a firm's evolution.

It is well known in the field of project management that firms (permanent operations) are distinct from projects (temporary endeavours) (Lundin and Söderholm, 1995; Engwall, 2003). However, some organisations (e.g., those that perform a main contractor role) have operations that are project-based (Gann and Salter, 2000; Davies et al., 2007; Whitley, 2006; and Winch, 2014). Project-based firms are distinct in that their goals and outputs are organised around multiple customer demands and the stability of their work roles, task organisation and so relationships 
must be fluid, temporary and evolving (Whitley, 2006). Five project case studies within one project-based firm demonstrate the temporary and evolving nature of a project-based firm as it moved away from transitional marketing to respond to the uniqueness and dynamic context of the firm's environment.

\section{Relationship Marketing in Project-based Firms}

Definitions of RM, over the last 30 years, show that this concept now has increased scope and pervasiveness from a single transaction to a broad system of exchanges. Table 1 summarises the evolution of RM definitions based on the seminal works that have greatly contributed to the area. Berry's (1983) definition moves marketing from attracting customers to maintaining them in order to benefit from a long-term relationship. Grönroos (1990) elaborates on the need to understand objectives on both sides of the relationship (i.e., the provider and the customer), while Gummesson (1994) extends the complex network of interactions beyond dyadic and formal relationships (i.e., 30 relationship principles). While Morgan and Hunt (1994) see its currency in all relational exchanges and beyond the singular buyer-seller exchange (e.g., six market model; Payne et al., 2005). This followed by Hunt et al.'s (2006) work that proposed relationship marketing success factors such as trust, complementary competence, internal market orientation and market-relating capabilities.

-- Insert Table 1 here --

Common in all these definitions is that $\mathrm{RM}$ is built on interactions between two or more actors and these interactions may have positive consequences. In fact, there has clearly been a "...significant shift in the axioms of marketing: competition and conflict to mutual cooperation, and choice independence to mutual interdependence" 
(Sheth and Parvatiyar, 1995, p. 399). Greater consideration is now given to higher quality relationships (with customers and wider stakeholders) and an axiomatic shift from individuality to mutuality. As has attention been given to strategies for achieving RM, such as: quality of service offering (Berry, 1995), the interaction of employees (Grönroos, 1995), the network of relationships (Gummesson, 1994) and the integration of the quality, customer service and marketing (Christopher et al., 2002). Hence, the shift from individuality to mutuality is considered as a core element of RM.

RM has been adopted by project-based firms, such as those in construction. Cova et al. (1996) showed that project-based firms have moved away from focusing on a single transaction of a project to building a long-term relationship with their customer base. The importance of RM for project-based and construction firms has also been highlighted. In the construction industry, Uher and Runeson (1985) indicated that good past relationships positively impact sub-contractor intentions to work again with a contractor. Alternatively, Plant (1989) argued that managing relationship is a core element for project managers, project teams and even overall project successes.

The discontinuity and temporal nature of projects presents a problem that relationship management can overcome through the on-going management of relationships after project completion. This makes RM even more crucial in projectbased firms. According to Hadjikhani (1996) and Skaates et al. (2002) this sleeping relationship strengthens trust and creates greater interdependence with the customer within and between projects. There is empirical support for this. Pinto et al. (2009) demonstrated that trust has a positive effect on satisfaction and project success. Jiang et al. (2012) proved that trust and dependence were antecedents of committed 
relationships that support communication and result in satisfaction. While Mazur et al. (2014) found that with the quality of both internal and external relationships contributed positively to success. Some studies have provided construction sector specific results. Bildsen (2014) found that quality relationships in house-building projects facilitated standardisation and generated future income. Furthermore, Akintoye and Main (2007) revealed that UK contractors engage in relationships to share risks, access innovation, advance technology, respond to the market, achieve resource efficiency and meet client requirements. Thus, RM is an important factor in shaping project-based and construction firms' performances.

Relationships have negative consequences as well. Grayson and Ambler (1999) showed that longer-term relationships have negative consequences such as rising expectations, a loss of objectivity and opportunism, which may negate the positive consequences of a relationship. The dark-side of relationship has been studied and explained in different ways, and some solutions have been explored to overcome these negative consequences (e.g., Anderson and Jap, 2005; Elsharnouby and Parsons, 2013; Fang et al., 2011; Villena et al., 2011). The negative consequences of relationship have also been investigated in construction and project contexts; for instance, Jin and Ling (2005) showed that an increasingly close relationship may lead to self-interest seeking actions and opportunistic behaviour. Consequently, they suggested applying trust-fostering tools such as effective selection and management of partners to avoid relationship risks.

Project-based firms apply different mechanisms to achieve a high quality relationship. Smyth and Fitch (2009) revealed that construction firms adopt key account management to implement the concept of RM. As a result, these firms benefit from cross-functional communication and collaboration, increased client 
satisfaction, and repeat business. Consistently, Ryals and Humphries (2007) showed that key account management in construction firms increases the quality of relationship through creating value, trust and reliability, increasing flexibility and responsiveness, reducing conflicts, and improving communication. The application of contracts is also an important mechanism in building relationships. Kadefors (2004) examined the role of contractual mechanisms in shaping the quality of the relationship between clients and construction firms, specifically the fact that traditional contracts with detailed specifications and a high level of control signal an environment of distrust that may lead to opportunism and hinder co-operative interactions. Investigating the nature of these relationships, Cova and Salle (2000) showed that project-based firms' relationships consist of social interactions on multiple levels (e.g., dyadic interactions with a project member and interactions within a project team). Cova and Salle (2000) implied that in this complex setting project managers can partially manage their relationship with other parties by establishing certain relationship rituals. Indeed, the extant literature has shown that organisational mechanisms such as key account management and contractual settings are important determinants of RM.

In addition to institutional mechanisms such as key account management and contractual mechanisms, agency plays a crucial role in provider-customer relationships. As an example of agency, Smyth and Edkins (2007) pointed out the difference between the reactive and proactive style of relationship building. They found that, in Private Public Partnerships and the Public Finance Initiative, the relationships are based on reactive actions to the relational contract; the suggestion is that proactive relationship building or relationship management is required in both the private and public sectors, given the long-term setting of Private Public 
Partnerships and the Public Finance Initiative. Focusing on the role of culture, Chen and Partington (2004) showed that Chinese and Western construction project managers have different approaches in their relationship with clients. They found that Chinese managers perceive the client as superior (and value a long-term relationship), whereas UK managers see the client as an equal contract party and value a mutually beneficial contract with the client.

RM research in project-based and construction firms has shown what the relationship mechanisms and their consequences are, but not why a project-based firm transforms from transactional marketing to RM. Unpacking this complexity may help to illuminate the transition of a project-based firm to RM and beyond.

\section{The Evolution of Service-Dominant Logic in Project-based Firms}

Bastiat (1860) criticised political economists who linked value to tangible objects, suggesting that efforts are transmitted in an exchange rather than goods and value is embedded in the use of material objects. Marketing academics followed the traditional economic theory of exchange, focusing on goods. The pre-1980s was the 'crawling out' period for service marketing emerging as a marketing sub-discipline (Fisk et al., 1993), yet marketing researchers approached service and service related phenomena using the Goods-Dominant logic view of marketing where services were perceived as anything other than goods (Vargo et al., 2006). Thereafter, a divergence could be observed from the Goods-Dominant logic towards a view that Bastiat (1860) had mentioned in order to describe service, service delivery and service consumption. For example, Prahalad and Ramaswamy (2004) argued that value is co-produced by parties (e.g., provider and customer) rather than being produced separately. This divergence led the establishment of a new dominant logic by Vargo and Lusch (2004) called Service-Dominant Logic (SDL). 
SDL is an emergent logic of exchange where operant, intangible resources are the basis of exchange rather than operand, tangible resources. In this logic, it is argued that applied, specialised skills and knowledge are the focus of any economic exchange. Therefore, individuals apply their own skills and knowledge to provide services and exchange needed services. In this process, goods may be transmitted as a mechanism in order to provide services for different parties (Vargo and Lusch, 2006). Indeed, in SDL, service is not defined as an alternative form of product; rather, it is labelled as "the application of specialised competences (Operant resources-knowledge and skills), through deeds, processes, and performances for the benefit of another entity or the entity itself"' (Vargo and Lusch, 2006, 43).

Over the last 10 years, marketing scholars have looked at projects with a view consistent with SDL. Cova and Salle (2005) argued that projects need to be redefined to include their long-term effect on customers' businesses. Consistently, Jalkala et al. (2010) explored the enlargement of the offering from project offering to solution offering that solve customer problems in the best way (as judged from the perspective of a customer). Enlargement of offering becomes a critical shift in thinking, however how and why firms make this transition requires greater consideration.

\section{Project as a Value Co-Creation Process}

Traditionally, value was perceived as embedded in products, and companies created the value through embedding it in their outputs (e.g. Beckman, 1957; Porter, 1980). However, in SDL value can only be proposed by a company and is created by the customer on the basis of value-in-use (Vargo and Lusch, 2008). In fact, the sixth SDL foundational premise is: "the customer is always a co-creator of value" (Vargo and Lusch, 2008, 7). This premise is similar to one of the core principles of RM, 
which is a move from individuality to mutuality. However, SDL assumes any product or service's consumption as a value co-creation process, while RM only focuses on situations where there is a relationship between the provider and the customer. This difference exists because SDL focuses on the interactions in a service exchange, whereas RM concentrates on interactions among actors. The notions of direct and indirect interactions help to differentiate these two levels of interaction. Direct interaction refers to the actors' actions, which are merged into a collaborative, dialogical process (Grönroos and Gummerus, 2014). In indirect interactions, the provider can produce resources and processes independently and the customer can use value proposition individually (Grönroos and Voima, 2013). Grönroos and Voima (2013) argued that value co-creation is a unique form of value creation where two or more actors such as a customer and a provider create value in a direct interaction and through a joint-process. Thus, in order to avoid confusion, indirect interactions are defined as value creation processes where customers are the only actors acting in the process. In other words, value co-creation is a specific situation where there is an interaction between actors through service exchange, therefore RM and SDL together can explain value co-creation process.

Project and construction management scholars have recently investigated value cocreation. Engagement has been one of the main factors investigated. Chang et al. (2013) argued that a project is a value co-creation process by showing how customers, providers and other stakeholders engage in a project to co-create value by balancing competing value of different stakeholders, specifically in the context of defence projects. Liu et al. (2014) examined early contractor involvement as an example of value co-creation. Furthermore, Hsu et al. (2013) demonstrated that the inclusion of customers in defining information system development projects is a 
determinant of project success in terms of system quality, user satisfaction and project performance. Contract co-development has been another example of a value co-creation process investigated in the construction and project management literature. By considering certain factors such as project complexity, aligned objectives and trust, Crespin-Mazet and Ghauri (2007) showed that co-developed contracts are more successful than traditional competitive contracts. Ahola et al. (2008) revealed that a close inter-organisational relationship creates long-term customer perceived value (e.g., image and trust), whereas a competitive tendering strategy generates short-term customer perceived value (e.g., on-time delivery and product performance). Researchers have also started looking at how value is cocreated in projects. For instance, Mele (2011) explained that conflicts in projects have positive and negative impacts on value co-creation. In particular, she suggested that un-resolved conflicts impede value co-creation.

As investigated in the literature, value co-creation helps companies to exploit their customers' resources to a wider extent (e.g., in production or in contract development) and improve their offerings through proposing resources and processes that are jointly developed by both parties. However, value co-creation is not able to explain the evolution of project-based firms beyond service exchanges. In fact, the transition of project-based firms from transactional marketing towards SDL and RM needs to be investigated beyond service exchanges to consider enterprise (business and environmental) elements and why and how project-based firms are being transformed towards SDL or RM.

\section{Method}

In this research, SDL and RM in project-based firms are elaborated through comparisons with the situation observed using a retroductive case study design and 
action research method. A pragmatic, reflective and retroductive design is applied, that involves referring to observed case studies to find patterns and to re-discover what produces them. Indeed, a critical realism paradigm is pursued where observed and non-observed events and experiences are in empirical and actual domains, and processes abs mechanisms shaping those experiences and events are in the real domain (Bhaskar, 2008). Critical realism, as is evident from its name, has a critical view of scientific discoveries; in fact, it encourages researchers to think beyond the existing theories and observations and explore and investigate new possible theories (Bhaskar, 1998). The data collection and analysis begin with observing regularities in the empirical domain. These observations are about the way different projects are set and managed over time. Then these observations are explained through SDL and RM as theoretical means to reflect the mechanisms generating those observations. Therefore, the research process relies on a retroductive research strategy. The retroductive strategy is based on a process for discovering a causal model responsible for an observable phenomenon; while induction is a theorisation of regularity based on a particular event and deduction is the theorisation of a regularity based on its generality, retroduction aims to identify the mechanisms generating the regularity (Blaikie, 2007).

Because the researcher was employed directly in a practice-based situation, the approach shares many elements with action research. Indeed, the research follows a retrospective action research method where the researcher participates in an actionbased context, which is analysed retrospectively (Gummeruss, 2000). Retrospective action research reduces the researcher bias as it detaches the research from the action. Furthermore, retrospective action research has the benefits of covert participant observation without raising any ethical conflict (Ballantyne, 2004). The 
longitudinal and historical research approach used is similar to that of Orum et al. (1991).

\section{$\underline{\text { Research Design }}$}

From 2002 to 2009 the first author was engaged with a main contractor working on oil, gas, petrochemical, mine, and metal industry projects in the Middle East (hereafter referred to as MidCo). In the context of MidCo, customers were mainly public or publicly funded organisations initiating projects in response to national or regional policies. In addition, there was a privatisation plan in the country, and the private sector was encouraged to define and invest in industrial projects. In these processes, new opportunities emerged for MidCo to help the customer-base in their project identification process through services such as feasibility studies, financial consultancy and front-end engineering design. Generally, after project identification and acceptance by customers, customers called for tenders and MidCo executed the projects in winning cases.

The researcher engaged with MidCo as design engineer, lead design engineer, engineering coordinator and risk management leader from 2002 to 2009. These activities provided access to all levels of the company through risk management workshops $(\mathrm{n}=11 \times 2 \mathrm{hr})$, contract negotiation meetings $(\mathrm{n}=9 \times 4 \mathrm{hr})$, quality management audits $(\mathrm{n}=2 \times 2$ days $)$, control system interviews $(\mathrm{n}=7 \times 1 \mathrm{hr})$, and coordination meetings $(\mathrm{n}=200 \times 2 \mathrm{hr})$. Notes were taken in these events and the main events at the project- and firm-levels were highlighted. These research interventions allowed detailed observation of and participation within five projects awarded consecutively over a seven-year period (each are given an anonymous letter from A to E, with A being awarded in 2001 and $\mathrm{E}$ in 2008). The investigation of consecutive projects provided an ideal dataset with which to explain the evolution of a single 
project-based firms (through temporal bracketing; Langley, 1999), and to describe why and how it moved away from transactional marketing to an alternative logic of marketing such as SDL or RM. Further interviews in 2015 validated the evolutionary propositions used to explain the changing nature of this organisation.

\section{$\underline{\text { Research Sample }}$}

The existing theory was re-examined within a single and convenient case study which has provided high exploratory potential and a holistic but contextual view of the processes to demonstrate the complex relationships between concepts (Eisenhardt, 1989; Fellows and Liu, 2002; Orum et al., 1991; Yin, 2003). The findings are therefore situated within a convenience sample, bounded by context and time. This provides an ideal way of explaining the theoretical parameters of SDL and RM and collecting evidence that allows both theory-testing and theory-building (Eisenhardt, 1989; Yin, 2003). Data was provided through the action-based involvement of the first author in one project-based firm. Indeed, the MidCo was the firm where the projects are embedded. Five projects that ran consecutively conveniently provided the basis for the research. Each case study project is different, although the clients were all public organisations, sharing similar processes and contextual elements:

- Project A: Engineering design and procurement services of a polymerization petrochemical plant. The project was awarded in 2001. The researcher was a design engineer and engaged in activities such as engineering design and reviews.

- Project B: Engineering design and procurement services of an Ammonia and Urea petrochemical plant. The project was awarded in 2003. The researcher was the leader of an engineering team involved in this project and engaged in 
activities such as the supervision of engineering design and procurement services activities.

- Project C: Engineering, procurement and construction of the off-site facilities and interconnections of a mega petrochemical complex. In this project, the main contractor was part of a consortium (including four other companies) managing the project. They had full responsibility for engineering activities and partial responsibility for procurement and construction activities. The project was awarded in 2003. The researcher was an engineering coordinator and engaged in activities such as design engineering, procurement services, construction coordination, and internal and external coordination.

- Project D: Engineering, procurement and construction of a Natural Gas Liquids extraction plant. The project was awarded in 2006. The researcher was the risk management leader and engaged in activities such as leading risk management process and knowledge transfer from other projects.

- Project E: Engineering, procurement and construction of an oil refinery plant. The project was awarded in 2008 . The researcher was the risk management leader and engaged in activities such as contract negotiation, leading risk management process and knowledge transfer from other projects.

\section{$\underline{\text { Research Data Collection and Analysis }}$}

A process research approach was used to thoroughly understand the case study as detailed by Langley (1999). The author's involvement in action has enabled a distinct narrative, descriptive and chronological account. According to Langley (1999, p. 691) "Process data are messy...[and so]... making sense of them is a constant challenge". She suggested that to provide "...coupling between theory and data" attention needs to be paid to the "sequences of events", "multiple levels and 
units of analysis", and inherent variances in the research method's precision, duration and relevance, as well as the fact that process data is affected by changing relationships, thoughts, feelings and interpretations.

The temporal and consecutive nature of the project data allowed the decomposition of data into discreet time periods (Langley, 1999). In fact, the collection and analysis of the data account for two temporal brackets: from 2001 to 2005 and from 2005 to 2009. In particular, the researcher acted in projects $\mathrm{A}, \mathrm{B}$ and $\mathrm{C}$ in the first bracket and involved in projects $\mathrm{D}, \mathrm{E}$ and to some extent $\mathrm{C}$ in the second bracket. The data analysis was based on the data collected in the meetings, workshops and interviews mainly based on the notes taken in these events. The data analysis was performed retrospectively as the research followed a retrospective action research (Gummeruss, 2000). In the first step of the data analysis, the events affecting MidCo and focal projects were openly coded into different categories entitled "business elements" (Table 2). For example, the way project success was associated with project members as a result of their level of engagement in the project was categorised as motivation element, as it determined the level of motivation in the project. In another example, the way performance was measured in projects (e.g., man-hour, project cost or overall project success) was coded as performance metrics. Indeed, longitudinal data from the case study was broken down into more homogeneous blocks (i.e., business elements), allowing a systematic and in-depth description of the temporal phases. This provided an illustration of embedded units of analysis as they emerged. Next, the events in each business elements are compared between two temporal brackets. For instance, the focus of skills has been changed from engineering design skills in the firs bracket to interpersonal skills in the second bracket. In fact, different business elements have been changed in the transition from transactional marketing 
towards SDL and RM as evident from temporal bracketing, which describes the evolution of projects and the events that contribute to their transactional, relational and service-led nature. In particular, the temporal bracket analysis showed the evolution of projects around three core categories of the expansion of services, interaction mechanisms and performance evaluation processes.

\section{Findings}

Business elements in temporal brackets are summarised in Table 2 and are explained further in the following sections. These elements suggest that project-based firm transitions can be explained through the evolution in the nature of projects, the delivery of services, the level of interactions and performance evaluation. Indeed, macro-environment and uncertainty elements mainly explain the evolution in the nature of projects, extent of contracts and services elements illuminate the transition in the delivery of services, communication and interaction mechanisms elements explain the changes in the level of interaction, and objectives, motivation and performance metrics elements describe the evolution in performance evaluation processes. This classification does not imply that these phenomena are independent from each other in business transitions, and some of the business elements such as risk and employees are used to explain different aspects of this transition. Indeed, it creates a platform for understanding the complexity of this transition.

$$
\text { -- Insert Table } 2 \text { here -- }
$$

Project environments are highly complex and so investigations of the evolution towards a service-led approach requires longitudinal investigation alongside the uniqueness and dynamics of the macro-environment factors that influenced the way MidCo operated its business activities. These are now defined. 


\section{MidCo's Enterprise Environment}

The dynamics of macro-environment factors influenced the way MidCo operated its business activities. The new government was appointed in 1997 and was able to facilitate oil and gas project financing through international funds and to increase income generation. Adopting a more reformist approach, there was a wide range of changes in the way projects were managed and outsourced by clients. These events encouraged main contractors such as MidCo to develop their capabilities and address the requirements in the market. For instance, projects A and B were engineering and procurement services projects, while projects C, D and E were lump sum turn key projects. MidCo operated in a dynamic environment due to raw material price fluctuations, technological changes, political changes, inflation rate fluctuations and low employee retention rates. This dynamic has caused projects to move a way from transactional marketing towards RM and SDL. For example, projects B, D and E benefited from adopting more collaborative processes such as co-location with clients and projects $\mathrm{C}, \mathrm{D}$ and $\mathrm{E}$ moved towards SDL through expansion of the scope of these projects.

The timescale of a typical project from the inception of the project idea until the achievement of objective (e.g., start-up of a petrochemical plant) was between four to ten years. This created a dynamic context for the project where many of the factors influencing the project were changing, including political (e.g., changes in the government), economical (e.g., inflation and price fluctuations), technical (e.g., technical changes in upstream projects) and operational factors (e.g., changes in the client team). From the empirical observation in project A (i.e., a petrochemical complex producing ethylene), the time schedule for the completion of the project was estimated to be four years. However, during the execution of the project the 
client realised that the upstream projects providing feed material to project A were delayed due to the re-arrangement of priorities in project delivery and would not be able to meet the four-year deadline for project A. On the other hand, MidCo invested in delivering the project within four years, potentially causing the client to suffer from non-working capital investment. As a result of these uncertainties, clients moved from individual management of risks and benefits of these projects to more collaborative arrangements.

Furthermore, as the characteristics of projects uniquely depend on the particular contextual situation of each customer (e.g., stakeholders of the project and location of facilities), direct interaction was necessary in project identification and execution. For example, in project $\mathrm{C}$ the capacity of utility systems changed during the project execution phase due to the changes in the client's requirements. Therefore, in addition to the association of project characteristics with the customer the project dynamic necessitated a move toward RM to achieve successful project definition and execution. In particular, an enhanced relationship was required in the projects to facilitate the flow of knowledge among stakeholders.

The performance of a project was not completely assessable until the project was delivered and used by the customer or their representative. In MidCo projects, the quality could only be completely appraised when the project outcomes (e.g., petrochemical and refinery plants) were delivered and used over time; in fact, in projects with a unique application of resources (e.g., an engineer creates a unique design for each project or the materials purchased are unique), focusing on project resources did not create an accurate evaluation of the project performance. This phenomenon shifted the exchange perspective in projects from the focus on resources to the focus on the application of resources (which is consistent with SDL). 
In other words, the process of applying resources focused on actors in the project exchanges as it provided more useful information. For example, performance metrics in MidCo shifted from resource metrics (e.g., man-hour and material costa) in projects $\mathrm{A}, \mathrm{B}$ and $\mathrm{C}$ to outcome based metrics (e.g., project delivery metrics and refinery and petrochemical plant performance in use) in projects D and E. Therefore, the uniqueness of the application of resources in projects demanded a shift from transactional marketing to SDL.

\section{Expansion of MidCo Services}

One of the important implications of adopting SDL and RM is the expansion of services. In MidCo, the projects were initially engineering projects where the contractor performed the design engineering phase and the subsequent phases such as procurement and construction were executed by the client or other actors (e.g., projects A and B). However, projects moved to turnkey projects where MidCo, as a general contractor, was responsible for all phases from investment consultancy to engineering, procurement, construction, commissioning and start-up of the facilities (e.g., projects $\mathrm{D}$ and $\mathrm{E}$, and to some extent project $\mathrm{C}$ ). It is anticipated that further expansion of services (e.g., project definition, operation and maintenance of facilities) could also improve the whole-life project success.

In the process of the expansion of services, clients moved away from individually taking risks and benefits to sharing them with providers. For example, in MidCo clients traditionally managed procurement activities which had higher portion of benefits and risks (e.g., projects A and B), however they realised that sharing such activities with the providers increases the success rate (e.g., projects $C, D$ and E). In particular, as procurement activities sometimes accounted for $70 \%$ of project costs, clients traditionally believed that they benefit further from managing these activities. 
However, risks associated with uncertainties and dynamics of the projects and interconnectedness of these activities required a more relational approach and a holistic view to the project. Besides, direct relationship between the main contractor and suppliers of the material became a necessary success factor in project, as it provided a basis for managing many of the uncertainty and interconnectedness issues. Furthermore, MidCo invested in building new capabilities in order to provide new services. From projects A, B and C to projects D and E, project finance, contract management, risk management, procurement and construction management were advanced in MidCo through hiring and personal development. Engineers also developed procurement and construction relevant skills, enabling them to manage the expansion of services effectively.

\section{MidCo’s Reorganisation to Form Multi-level Distributed Interactions}

The way the provider and customer interact was altered in MidCo. Traditionally, the interactions between the customer and provider primarily occurred between project managers and their counterparts in client organisations (e.g., project A). Over time, further interactions occurred among project stakeholders in regular meetings or in ad-hoc problem solving meetings (e.g., projects B and C). In projects D and E, both customer and provider agreed to co-locate the project actors to facilitate direct interactions. Indeed, interactions were evident at different levels (e.g., senior management, project management, technical experts etc.) with more informal problem solving oriented settings. This created a network of relationships among the members engaged in the project, leading to further challenges and opportunities in managing relationships. Indeed, different networks benefited from varied quality of relationships; while an engineering group created a strong relationship with other stakeholders (e.g., the client, the managing consultant and other internal engineering 
disciplines), another engineering group could not manage the relationships very well. This raised a business-level initiative to improve communication and relationship building skills at an individual level. In other words, MidCo created dyadic relationships with other businesses through senior management and project managers in projects $\mathrm{A}$ and $\mathrm{B}$, whereas it shaped its relationship with other actors through a network of interactions among all project members in projects $\mathrm{D}, \mathrm{E}$ and to some extent C.

In the process of moving from single point interactions to distributed interactions, MidCo created capabilities in its human resources to be able to achieve distributed interaction arrangement. Firstly, in projects D and E and to some extent projects B and C, MidCo identified experts with acceptable communication skills and provided them with responsibility for managing the interactions at different levels (e.g., project level, engineering discipline level, procurement management level etc.) with customer representatives and other stakeholders. Therefore, in addition to technical skills, interpersonal skills were important to facilitate interactions. Secondly, MidCo empowered these actors with the authority to decide on issues under their control. For example, engineers were authorised to decide on technical issues within a certain financial threshold in projects D and E.

Distributed interactions helped project stakeholders to manage problem solving at multiple intra-organisation and inter-organisation levels. For example, in project D MidCo's CEO interacted with competitors to approach the government to find a solution for project problems raised by metal price fluctuations. Internal interaction also provided appropriate knowledge about the consequences of decisions regarding other stakeholders of the project. For instance, an engineering decision could have a huge impact on procurement and construction activities. In fact, interactions as a 
communication mechanism facilitated learning and knowledge about the interrelationships among project events.

\section{MidCo's Move Towards Process-Oriented Performance Evaluation}

One of the important implications of adopting SDL and RM is its impact on the way performance is defined and evaluated. Traditionally, performance was defined and evaluated based on the amount of resources integrated in a project. For example, in projects A and B man-hours were the main performance indicator. This view shifted from associating performance with resources to defining it in terms of the application of resources. In order to achieve this, performance was evaluated based on outcomes as proxies of processes. For example, in project $\mathrm{C}$ engineering design performance was associated with the number of drawings that were approved for construction. Alternatively, in projects $\mathrm{D}$ and $\mathrm{E}$ the procurement performance was evaluated based on the effect of materials purchased on other project activities (e.g., construction activities, cost of other materials, plant performance after project completion etc.).

The outcomes of each stage of a project were used in the subsequent stages. Therefore, looking at the outcomes without considering their impact on the whole project was problematic, and thus quality criteria were established to anticipate the future impact of each stage. In projects $\mathrm{D}$ and $\mathrm{E}$ for example, the engineering documents were evaluated to anticipate their impact on the procurement and construction phases. Furthermore, purchased products were inspected to ensure they would function properly. Nevertheless, this was a challenging task as it needed engagement with or knowledge about stakeholders who were not directly interacting with the project (e.g., operators of the facility). This was one of the main reasons for the expansion of services, creating knowledge about and engagement with a further range of stakeholders and facilitating the communication of performance metrics 
throughout the project. For example, communicating construction phase requirements was much easier in an integrated engineering, procurement and construction project (i.e., projects D and E) compared to engineering only projects (i.e., projects $\mathrm{A}$ and $\mathrm{B}$ ).

In addition, it was observed that as a result of the project characteristics (i.e., uniqueness and dynamics) the actual events might not occur as they were anticipated. Therefore, taking risks individually by a client or transferring risks to a provider (projects A and B) did not improve the overall performance of the projects. In the MidCo projects D and E, where risks and benefits were shared between the provider and the customer, they had more flexibility and responsiveness to respond to events that were not anticipated. For example, in these projects benefits from a design engineering cost reductions shared between the client and MidCo. This further moved the view of both customer and provider from the planning approach to the experiment approach of managing projects, meaning that the actual performance is embedded in the process of integrating resources and not the outcome of that process. In other words, past events defined what is the best process for project success and actors' performance needed to be evaluated in the sense of how these processes were anticipated and shaped and were able to adapt to the unique events in each project. For example, in a design engineering activity it was important to see how information was collected, analysed, interpreted and used. However, mechanisms supporting this view were less evident in MidCo as the business and contextual elements were not sufficiently advanced to support them. Associating performance with the process required a high level of trust among actors at different levels (i.e., intra-organisational and inter-organisational), otherwise there was a possibility of opportunistic behaviour. Furthermore, the motivation of all actors 
needed to shift from gaining more resources to facilitating problem solving by using resources. Therefore, before any further shift in performance management, MidCo needed to create mechanisms that can develop such a culture.

\section{Discussion}

As observed in MidCo, the project uniqueness and dynamics require a view adopting both SDL and RM that enables firms to successfully manage these projects. This view is entitled the service-led relationship (SLR) and is built on two major developments in marketing thoughts: SDL and RM. Indeed, RM is a shift from individuality to mutuality (Sheth and Parvatiyar, 1995) and SDL is a shift from goods exchange to service exchange (Vargo and Lusch, 2004). These views describe two dimensions of marketing: relationship and exchange. Based on these two dimensions, it is possible to identify four possible marketing views explaining the interactions between the provider and customer (Figure 1).

\section{-- Insert Figure 1 here --}

Marketing practices have moved from transactional marketing to practices aligned with SDL, RM or both. Some practices are aligned with RM with no attachment to SDL, such as loyalty programmes and customer lifetime value management. Other practices have adopted SDL view and have no linkage with RM, such as IKEA's provision of flexible resources, which can be integrated independently by the customer in use situations through indirect interactions. While any problem-solving collaborative process can be viewed as SLR. In general, value co-creation, which is extensively used in the literature, is the manifestation of adopting both SDL and RM. Indeed, the main goal of SLR is to maximise value-in-use through joint processes and direct interactions between the customer and provider. 
However, there are marketing processes such as those highlighted in MidCo that can be explained through SLR; MidCo projects moved from transactional marketing towards SLR (Figure 1). MidCo projects are relatively mapped on Figure 1 according to the practices they adopt that are explained in Table 2. For instance, Project $\mathrm{C}$ provided a wider range of services than Project $\mathrm{B}$ and achieved a higher score towards a service focus of exchange. However, Project $\mathrm{C}$ received a lower rate towards a relationship-based interaction than Project B due to the adoption of colocation mechanism in Project B that was not observed in Project C.

Smyth (2015) suggested that the purpose of a relationship defines the way RM is adopted. The purpose ranges from transactional management to relationship management. In relationship management, $\mathrm{RM}$ is adopted to facilitate learning about both the customer's needs and the provider's capabilities. In project-based and construction firms, the uniqueness of the project and its association with the customer necessitates relationship building to facilitate communication between customer needs and provider value propositions. The purpose of the relationship is to maximise value creation in the one-off exchange of a project, rather than customer lifetime value (e.g., Christopher et al., 2002). In fact, the main goal in SLR is problem solving and the relationship works as a mechanism to achieve this goal.

\section{Expansion of Project Services Builds a Dynamic Project-based Firm}

The expansion of services responds to the uncertainties and challenges resulting from a project's dynamics and uniqueness by facilitating the flow of knowledge. Others have described the influence of value creation (Vargo and Lusch, 2006, 43), and the importance of projects, integrated systems and enlarged offering in addressing the long-term effect on a customer's business (Cova and Salle, 2005; Davies et al., 2006; Jalkala et al. 2010), however these studies focus on the integration of goods and 
services that address the customer requirements in a project. SLR shifts the focus from the customer to the project stakeholders, including final users and operators of the project outcomes. Although in MidCo the expansion of services was implemented in order to address customers' needs, it is anticipated that further expansion of services in the project front-end (e.g., project definition, investment etc.) and back-end (e.g., facility management, end customer management, operations etc.) would facilitate project value co-creation. Indeed, provider firms are moving away from specialised service providers to service integrators. The expansion of services helps providers to facilitate the flow of knowledge among stakeholders; as projects become more unique and dynamic, it is crucial to facilitate the flow of knowledge. The expansion of services creates this flow by linking related services and establishing a platform for further engagement with stakeholders.

\section{Co-creation Requires Multi-level Distributed Interactions}

As an emerging finding, multi-level distributed direct interactions, as the core element of value co-creation, were identified as a mechanism to respond to the uncertainties and challenges resulting from a project's dynamics and uniqueness through the co-creation of actions. Recent developments in SDL have also acknowledged the co-creation of value by multiple actors (Vargo and Lusch, 2016). Here, direct interactions are mechanisms that facilitate problem-solving activities. Therefore, they are mechanisms for generating ideas and communicating information rather than settings used for influencing other actors. In particular, in project-based firms the uniqueness and dynamics of events create a complex setting where problem solving in an indirect interaction is less efficient. Therefore, in SLR interactions include constructive actions such as making decisions, changing existing activities and defining new activities. These co-created actions lead to value co-creation in 
projects. Thus, value co-creation is a mechanism that project-based firms adopt to respond to the uncertainties and challenges in projects. In other words, an SLR interaction is a generative mechanism rather than a symbolic event.

\section{Process-Oriented Performance Management Drives Project Success}

Process-oriented performance management improves project successes by integrating the best available resources and processes that potentially meet the project objectives. The transition from resource measures to process metrics is consistent with the value-in-use definition (e.g., Grönroos and Voima, 2013). This also extends the definition of performance to the future effect of the processes. Indeed, as observed in MidCo the outcomes of each stage of a project influence the subsequent service exchanges. Thus, in addition to the process and the outcomes of the process, performance should consider the actual effects of these outcomes (i.e., value-in-use). The expansion of services is a mechanism that creates a platform for firms to be able to evaluate the performances of more services in use. Direct interactions with other stakeholders of the project also facilitate the anticipation of value-in-use. In SLR, cost and time are less able to cover the range of information about performance. Time and cost may only reflect the efficiency element of one phase of a project, while sometimes its future effects have wider impacts for the stakeholders. Therefore, in project-based firms performance management mechanisms should move further towards process-based performance metrics. In this view, motivation, culture, competencies and relationship quality (i.e., with the purpose of learning (Smyth, 2015)) are more important than time and cost milestones. 


\section{Conclusion}

The findings are concluded in three categories. Firstly, the findings showed that the uniqueness and dynamics of project-based firms necessitate a move from traditional marketing to SLR. In fact, the uniqueness is the core characteristic of a project and it can create uncertainty. Furthermore, dynamics of projects generate more complex events that are not easily addressed with transactional view. Therefore, project-based firms adopt practices relying on building relationships with other stakeholders and focusing on service exchange, so as to address these challenges.

Secondly, findings revealed that project-based firms adopt SLR through the expansion of services, the development of multi-level direct interactions and a redefinition of performances. The expansion of services improves the flow of knowledge among actors providing services. Moreover, the main purpose of multilevel direct interactions in SLR is to build new resources and processes in response to the dynamics of a project in order to facilitate project value creation. Processoriented performance management also increase the possibility of integrating the best available resources required to meet the project objectives.

Thirdly, the findings suggested that the movement from traditional marketing to SLR occurs through building capabilities, cultures and mechanisms that support the new way of thinking. Indeed, the mechanisms required to achieve SLR include improving individual capabilities such as communication and interpersonal skills, creating a culture supporting self-motivation and problem-solving, and providing institutional mechanisms supporting SLR such as contractual and technical platforms.

\section{Theoretical Contributions}


The findings contribute to the RM literature by explaining the way it helps firms to solve their problems. Indeed, the dark side of relationship found in construction project-based firms (e.g., Jin and Ling, 2005) results from pure RM with no SDL orientation; pure RM focuses primarily on actors' relationships, sometimes defining long-term relationship as the goal of RM (e.g., Berry, 1983) as it highlights the exchange of resources and views value as embedded in these resource exchanges (or in the frequency of resource exchanges). In this view, loyalty, repeat purchase and long term relationship are consequences of RM. However, the findings indicate that in project-based firms with a high degree of uniqueness and dynamics such as construction firms, a service-led relationship can enable positive consequences whilst diminishing the negative side of relationship, considering problem-solving as the main goal of a relationship.

Extant project and construction management literature on relationship supports the above argument that high quality relationships facilitate project success (e.g., Akintoye and Main, 2007; Bildsen, 2014; Jiang et al., 2012; Mazuret al., 2014; Pinto et al., 2009). This line of thought can be advanced as relationship quality and project success evolve simultaneously. Indeed, the movement from transactional marketing to service-led relationship not only improves the definition and execution of projects, but also creates high quality relationships among stakeholders. Practices such as distributed interactions, shared risk contracts, co-location, and outcome-based and process-based performance metrics improve relationship quality and project success at the same time.

The findings further highlight the role of agency in moving towards SLR. Existing project and construction management studies have highlighted the role of people and culture in shaping relationships (e.g., Chen and Partington, 2004; Cova and Salle, 
2000; Smyth and Edkins, 2007). The findings further illustrate that individual capabilities, attitude and culture are building blocks of a service-led relationship. In other words, setting shared risk contracts, distributed interactions and outcome-based performance evaluations and expanding services create positive consequences only if there are people who are able to act in these institutional mechanisms and who have a shared understanding of their interactions, actions and goals.

The findings also contribute to the literature on SDL in project-based and construction firms. Consistent with Cova and Salle (2005) and Jalkala et al. (2010), the findings show a movement to the expansion of services in project exchanges. There is further evidence that this expansion of services occurs along with the redefinition of performance, interactions, and the mechanisms supporting these phenomena. In other words, in SLR the expansion of services is in line with the development of relationships in project exchanges. In fact, the necessity for direct interaction and relationship quality in project exchanges, as highlighted by SDL researchers (e.g., Ahola et al., 2008; Chang et al., 2013; Crespin-Mazet and Ghauri, 2007; Hsu et al., 2013) is explained. Direct interactions or in a broader sense relationship building facilitates the creation of value embedded in the application of resources in project exchanges.

\section{Limitations and Future Research}

The findings attained here are explored based on a single action-based case study of a main contractor in the oil and gas industry. This limits the generalisation of findings to other contexts such as IT project-based firms or construction firms in other industries. Further research is required to investigate the transition of projectbased firms in other contexts so as to explain the commonalities and differences in the transition process from transactional marketing towards SLR, RM or SDL. 
The findings illustrate that there has been a move towards SLR in MidCo. However, it does not guarantee that this transition endures. Over time, cycles might exist where transactional approaches are balanced in time by relational and service-led features. Indeed, the extent to which projects are unique and dynamic depends on the complexity of their environment; therefore, the results may rely on the specific level of complexity in the projects environmental factors. Further research is recommended in order to explore project-based firms' transitions in different environments to specify the role of the environment in the way they transform their marketing logic.

Furthermore, as an action research, the data collection and analysis have focused on the events relevant to the actions taken by the researcher. Therefore, in the transition from transactional marketing towards SLR there might be events not being observed explaining other aspects of this transition. For instance, the actions explained in the findings were less related to accounting and finance system of MidCo and could not reflect on the way they evolved (or stayed as they were). Hence, further research is suggested to investigate the development of project-based firms looking at different aspects of the firms. In-depth case studies, ethnographies and participant observation are potential methods that can complement this research.

The process nature of the data provided the opportunity to explain the overall transition of a project-based firm and identify main elements in this development. However, these theoretical models need further covariance-based investigations to achieve theoretical validity (i.e., internal and external validity). Thus, further research is recommended to operationalise and examine different concepts identified in this research adopting covariance-based approach. 
Future research needs to look at the mechanism and capabilities that project-based firms require to develop in order to implement SLR further. These mechanisms could be contractual arrangements that support both high quality relationships and service orientations. Mechanisms engaging whole-life project stakeholders in the definition and execution of the project could also be investigated to facilitate the transition towards SLR. In addition, further research needs to explain the way cultural aspects of project-based firms can support SLR.

\section{Recommendations}

The core focus of SLR is value rather than customer, project or relationship. In other words, in SLR, in addition to project delivery and responsiveness, flexible resource integration is a core capability to maximise value. In the process of adopting SLR, firms continuously generate new resources and processes which can be applied to solve problems in the project exchange and can be communicated to achieve new project exchanges. Therefore, investing in dynamic capabilities such as new product, process and business development creates strategic benefits for project-based firms.

Value co-creation emerged as a way project-based firms can respond to the uncertainty of complexity of projects. Indeed, moving away from individually managing risks and benefits to mutually creating joint-processes and sharing risks and benefits provides more opportunities for solving problems a project faces. Dynamic and unique projects need further value co-creation in order to manage the high level of uncertainty and complexity.

Project-based firms need to re-define and develop individual-level capabilities, so as to change individual responsibilities from task-oriented towards value-oriented ones. For instance, an engineer responsible for completing engineering design needs to 
develop capabilities such as procurement services, construction supervision, and operations and maintenance review of a petrochemical plant development project. The expansion of services can facilitate such capability development by enhancing the flow of knowledge between service provider actors.

Furthermore, project-based firms adopting SLR change their performance management processes from input-oriented systems towards outcome and processoriented ones. However, this transition requires a strong culture encouraging selfmotivation and appreciating individual successes in line with project success. Indeed, service provider actors need to manage their activities in a way that leads to the integration of the best available resources and the generation of the best potential resources.

Finally, project-based firms need to develop mechanisms (or platforms) in line with SLR. These mechanisms include legal, technological and financial platforms affecting culture and capabilities in projects. For instance, information systems and project contracts should enable the expansion of services, or employee contracts and reward systems should enhance self-motivation culture.

Indeed, the following recommendations are made for construction and project-based firms:

- The main focus of construction project-based firms needs to be on flexibly generating resources rather than exploiting existing resources.

- Construction and project-based firms need to develop capabilities to engage in direct interactions with project stakeholders in order to solve complex project problems. 
- Construction and project-based firms benefit from investing in developing individual-level capabilities to include value-related expertise from the inception of a project to the post-completion of that project.

- Culture, capabilities and mechanisms supporting process-oriented performance management fits with the nature of complex (unique and uncertain) projects.

- Construction and project-based firms benefit from investing in co-creation platforms such as information systems, contractual and financial agreements. 


\section{References}

Ahola, T., Laitinen, E., Kujala, J. and Wikström, K. (2008) Purchasing strategies and value creation in industrial turnkey projects. International Journal of Project Management, 26(1), 87-94.

Akintoye, A. and Main, J. (2007) Collaborative relationships in construction: the uk contractors' perception. Engineering, Construction and Architectural Management, 14(6), 597-617.

Anderson, E. and Jap, S.D. (2005) The dark side of close relationships. MIT Sloan Management Review, 46(3), 75-82+93.

Ballantyne, D. (2004) Action research reviewed: a market-oriented approach. European Journal of Marketing, 38(3/4), 321-337.

Bastiat, F. (1860) Harmonies of Political Economy, Sterling P.S. (Translation), J. Murray, London.

Beckman, T.N. (1957) The value added concept as a measurement of output. Advanced Management, 22(2), 6-9.

Berry, L.L. (1983) Relationship marketing, in Berry, L.L., Shostack, G.L. and Upah, G. (eds), Emerging Perspectives on Services Marketing, American Marketing Association, Chicago, IL, pp. 25-8.

Berry, L.L. (1995) Relationship marketing of services: growing interest, emerging perspectives. Journal of the Academy of Marketing Science, 23(4), 236-245.

Bhaskar, R. (1998) The Logic of Scientific Discovery, in Archer, M., Bhaskar, R. Collier, A., Lawson, T. and Norrie, A. (eds) Critical Realism: Essential Readings, Routledge, London, pp. 48-103. 
Bhaskar, R. (2008) A Realist Theory of Science, Routledge, Oxon, UK.

Bildsten, L. (2014) Buyer-supplier relationships in industrialized building. Construction Management and Economics, 32(1-2), 146-159.

Blaikie, N. (2007) Approaches to Social Enquiry, 2nd Edn. Polity Press, Cambridge. Bridgens, R. (2007) Autoethnography and untold stories. Qualitative Researcher, 4, 4-6.

Chang, A., Chih, Y.Y., Chew, E. and Pisarski, A. (2013) Reconceptualising mega project success in Australian defence: recognising the importance of value cocreation. International Journal of Project Management, 31(8), 1139-1153.

Chen, P. and Partington, D. (2004) An interpretive comparison of Chinese and western conceptions of relationships in construction project management work. International Journal of Project Management, 22(5), 397-406.

Christopher, M., Payne, A. and Ballantyne, D. (2002) Relationship Marketing: Creating Stakeholder Value, Butterworth-Heinemann, Oxford, UK

Cova, B. and Salle, R. (2000) Rituals in managing extra business relationships in international project marketing: a conceptual framework. International Business Review, 9(6), 669-685.

Cova, B. and Salle, R. (2005) Six key points to merge project marketing into project management. International Journal of Project Management, 23(5), 354-359.

Cova, B., Mazet, F. and Salle, R. (1996) Milieu as a pertinent unit of analysis in project marketing. International Business Review, 5(6), 647-664. 
Crespin-Mazet, F. and Ghauri, P. (2007) Co-development as a marketing strategy in the construction industry. Industrial Marketing Management, 36(2), 158-172.

Davies, A., Brady, T. and Hobday, M. (2006) Charting a path toward integrated solutions, MIT Sloan Management Review, 47(3), 39-48.

Davies, A., Brady, T. and Hobday, M (2007) Organizing for Solutions: Systems seller vs. systems integrator, Industrial Marketing Management, 36(2), 183-193.

Doloriert, C. and Sambrook, S. (2012) Organisational autoethnography. Journalof Organizational Ethnography, 1(1), 83-95.

Engwall, M. (2003) No project is an island: linking projects to history and context, Research Policy, 32(5), 789-808.

Eisenhardt, K.M. (1989) Building theories from case study research. Academy of Management Review, 14(4), 532-550.

Elsharnouby, T. and Parsons, E. (2013) When relationship marketing goes wrong: opportunism and consumer well-being in consumer-bank relationships. Journal of Relationship Marketing, 12(2), 141-163.

Fang, S.R., Chang, Y.S. and Peng, Y.C. (2011) Dark side of relationships: a tensions-based view. Industrial Marketing Management, 40(5), 774-784.

Fellows, R. and Liu, A. (2002) Research Methods for Construction, Blackwell Publishing Company, Oxford, UK.

Fisk, R.P., Brown, S.W. and Bitner, M.J. (1993) Tracking the evolution of the services marketing literature. Journal of Retailing, 69(1), 61-103. 
Gann, D. and Salter, A.J. (2000) Innovation in project-based, service-enhanced firms: The construction of complex products and systems. Research Policy, 29(7-8), 955-972.

Grayson, K. and Ambler, T. (1999) The dark side of long-term relationships in marketing services. Journal of Marketing Research, 36(1), 132-141.

Grönroos, C. (1990) Service Management and Marketing: Managing the Moments of Truth in Service Competition, Free Press-Lexington Books, Lexington, MA.

Grönroos, C. (1994) From marketing mix to relationship marketing. Management Decision, 32(2), 4-20.

Grönroos, C. (1995) Relationship marketing: the strategy continuum. Journal of the Academy of Marketing Science, 23(4), 252-254.

Grönroos, C. and Gummerus, J. (2014) The service revolution and its marketing implications: service logic vs service-dominant logic. Managing Service Quality, 24(3), 206-229.

Grönroos, C. and Voima, P. (2013) Critical service logic: making sense of value creation and co-creation. Journal of the Academy of Marketing Science, 41(2), 133150.

Gummesson, E. (1994) Making relationship marketing operational. International Journal of Service Industry Management, 5(5), 5-20.

Gummesson, E. (2000) Qualitative Methods in Management Research, Sage, Thousand Oaks, CA.

Gummesson, E. (2007) Exit services marketing - enter service marketing. Journal of Customer Behaviour, 6(2), 113-141. 
Gummesson, E. and Male, C. (2010) Marketing as value co-creation through network interaction and resource integration. Journal of Business Market Management, 4(4), 181-198.

Hadjikhani, A. (1996) Project marketing and the management of discontinuity. International Business Review, 5(3), 319-336.

Hayano, D. (1979) Auto-ethnography: paradigms, problems and prospects. Human Organization, 38(1), 99-103.

Holbrook, M.B. (2005) Customer value and autoethnography: subjective personal introspection and the meanings of a photograph collection. Journal of Business Research, 58(1), 45-61.

Hsu, J.S., Hung, Y.W., Chen, Y.H. and Huang, H.H. (2013) Antecedents and consequences of user coproduction in information system development projects. Project Management Journal, 44(2), 67-87.

Hunt, S.D. Arnett D.B. and Madhavaram, S. (2006) The explanatory foundations of relationship marketing theory. Journal of Business and Industrial Marketing, 21(2), $72-87$.

Jacobsson, M. and Roth, P. (2014) Towards a shift in mindset: partnering projects as engagement platforms. Construction Management and Economics, 32(5), 419-432.

Jalkala, A., Cova, B., Salle, R. and Salminen, R.T. (2010) Changing project business orientations: towards a new logic of project marketing. European Management Journal, 28(2), 124-138.

Jiang, Z., Henneberg, S.C. and Naudé, P. (2011) Supplier relationship management in the construction industry: the effects of trust and dependence. Journal of Business and Industrial Marketing, 27(1), 3-15. 
Jin, X.H., Doloi, H. and Gao, S.Y. (2007) Relationship-based determinants of building project performance in China. Construction Management and Economics, 25(3), 297-304.

Jin, X.H. and Ling, F.Y.Y. (2005) Constructing a framework for building relationships and trust in project organizations: two case studies of building projects in China. Construction Management and Economics, 23(7), 685-696.

Kadefors, A. (2004) Trust in project relationships-inside the black box. International Journal of Project Management, 22(3), 175-182.

Kociatkiewicz, J. and Kostera, M., (2012) The speed of experience: the co-narrative method in experience economy education. British Journal of Management, 23(4), 474-488.

Langley, A. (1999) Strategies for Theorizing from Process Data. The Academy of Management Review, 24(4), 691-710.

Liu, A.M.M., Fellows, R. and Chan, I.Y.S. (2014) Fostering value co-creation in construction: a case study of an airport in India, International Journal of Architecture, Engineering and Construction, 3(2), 120-130.

Lucas, M., (2014) 'Nomadic' organization and the experience of journeying: through liminal spaces and organizing places. Culture and Organization, 20(3), 196-214.

Lundin, R.A. and Söderholm, A. (1995) A theory of the temporary organization. Scandinavian Journal of Management, 11(4), 437-455.

Mazur, A., Pisarski, A., Chang, A. and Ashkanasy, N.M. (2014) Rating defence major project success: the role of personal attributes and stakeholder relationships. International Journal of Project Management, 32(6), 944-957. 
Mele, C. (2011) Conflicts and value co-creation in project networks. Industrial Marketing Management, 40(8), 1377-1385.

Morgan, R.M. and Hunt, S.D. (1994) The commitment-trust theory of relationship marketing. Journal of Marketing, 58(3), 20-38.

Morris, P.W.G. (2002) Science, objective knowledge and the theory of project management. Proceedings of the ICE - Civil Engineering, 150(2), 82-90.

Orum, A.M., Feagin, J.R. and Sjoberg, G. (1991), Introduction: the nature of case study, in Feagin, J., Orum, A. and Sjoberg, G. (Eds), A Case for the Case Study, University of North Carolina Press, Chapel Hill, NC.

Pink, S., Tutt, D., Dainty, A. and Gibb, A. (2010) Ethnographic methodologies for construction research: knowing, practice and interventions. Building Research and Information, 38(6), 647-659.

Pinto, J.K., Slevin, D.P. and English, B. (2009) Trust in projects: an empirical assessment of owner-contractor relationships. International Journal of Project Management, 27(6), 638-648.

Plant, N. (1989) Managing the client relationship (with a little help from methodologies). International Journal of Project Management, 7(1), 33-35.

Porter, M.E. (1980) Competitive Strategy: Techniques for Analyzing Industries and Competitors, The Free Press, New York.

Prahalad, C.K. and Ramaswamy, V. (2004) Co-creation experiences: the next practice in value creation. Journal of Interactive Marketing, 18(3), 5-14. 
Rod, M. and Beal, T. (2014) The experience of New Zealand in the evolving wine markets of Japan and Singapore. Asia-Pacific Journal of Business Administration, 6(1), 49-63.

Ryals, L.J. and Humphries, A.S. (2007) Managing key business-to-business relationships: what marketing can learn from supply chain management. Journal of Service Research, 9(4), 312-326.

Sheth, J.N. and Parvatiyar, A. (1995) The evolution of relationship marketing. International Business Review, 4(4), 397-418.

Sivunen, M., Pulkka, L., Heinonen, J., Kajander, J.K. and Junnila, S. (2013) Servicedominant innovation in the built environment. Construction Innovation, 13(2), 146164.

Skaates, M.A., Tikkanen, H. and Lindblom, J. (2002) Relationships and project marketing success. Journal of Business and Industrial Marketing, 17(5), 389-406.

Smyth, H.J. (2015) Market Managing and Project Business Development, Routledge, New York.

Smyth, H.J. and Edkins, A. (2007) Relationship management in the management of PFI/PPP projects in the UK. International Journal of Project Management, 25(3), 232-240.

Smyth, H.J. and Fitch, T. (2009) Application of relationship marketing and management: a large contractor case study. Construction Management and Economics, 27(4), 399-410.

Turner, J.R. and Müller, R. (2003) On the nature of the project as a temporary organization. International Journal of Project Management, 21(1), 1-8. 
Uher, T.E. and Runeson, G. (1985) Subcontractor-general contractor relationship in Australian building industry. International Journal of Project Management, 3(1), 3538.

Vargo, S.L. and Lusch, R.F. (2004) Evolving to a new dominant logic for marketing", Journal of Marketing, 68(1), p. 1-17.

Vargo, S.L. and Lusch, R.F. (2006) Service-dominant logic: what it is? what it is not? and what it might be? in Lusch, R.F and Vargo, S.L. (eds), The Service Dominant Logic of Marketing, M.E. Sharpe, New York, pp. 43-56.

Vargo, S.L. and Lusch, R.F. (2008) Service-dominant logic: continuing the evolution. Journal of Academy of Marketing Science, 36(1), 1-10.

Vargo, S.L. and Lusch, R.F. (2010) From repeat patronage to value co-creation in service ecosystems: a transcending conceptualization of relationship. Journal of Business Market Management. 4(4), 169-179.

Vargo, S.L. and Lusch, R.F. (2016) Institutions and axioms: An extension and update of service-dominant logic. Journal of Academy of Marketing Science, 44(1), 5-23.

Vargo, S.L. and Lusch, R.F. and Morgan, F.W. (2006) Historical perspectives on service-dominant logic. in Lusch, R.F and Vargo, S.L. (eds), The Service Dominant Logic of Marketing, M.E. Sharpe, New York, pp. 29-42.

Villena, V.H., Revilla, E. and Choi, T.Y. (2011) The dark side of buyer-supplier relationships: a social capital perspective. Journal of Operations Management, 29(6), $561-576$.

Winch, G. (2014) Three domains of project organising. International Journal of Project Management, 32(5), 721-731. 
Whitley, R. (2006) Project-based firms: New organizational form or variations on a theme? Industrial and Corporate Change. 15(1), 77-99.

Yin, R.K. (2003) Case Study Research: Design and methods, Sage Publications, London. 
Table 1, Views on Relationship Marketing

\begin{tabular}{|l|l|}
\hline Author, Year, p. & \multicolumn{1}{c|}{ Views on Relationship Marketing } \\
\hline Berry, 1983, 25 & $\begin{array}{l}\text { "attracting, maintaining and -in multi-service organizations- } \\
\text { enhancing customer relationships" }\end{array}$ \\
\hline $\begin{array}{l}\text { Grönroos, 1990, } \\
38\end{array}$ & $\begin{array}{l}\text { "Marketing is to establish, maintain, and enhance relationships } \\
\text { with customers and other partners, at a profit, so that the objectives } \\
\text { of the parties involved are met. This is achieved by a mutual } \\
\text { exchange and fulfilment of promises" }\end{array}$ \\
\hline $\begin{array}{l}\text { Gummesson, } \\
1994,5\end{array}$ & "marketing seen as relationships, networks, and interaction" \\
\hline $\begin{array}{l}\text { Morgan and Hunt, } \\
1994,22\end{array}$ & $\begin{array}{l}\text { "relationship marketing refers to all marketing activities directed } \\
\text { towards establishing, developing, and maintaining successful } \\
\text { relational exchanges" }\end{array}$ \\
\hline
\end{tabular}


Table 2, The Transition of Business Elements in MidCo

\begin{tabular}{|c|c|c|c|c|c|}
\hline \multirow{2}{*}{$\begin{array}{l}\text { Business } \\
\text { Elements }\end{array}$} & \multirow{2}{*}{ Data Source } & \multicolumn{2}{|c|}{ Temporal Brackets Grouped by Project A-E } & \multicolumn{2}{|c|}{ Transition } \\
\hline & & Before transition & During and after transition & From & To \\
\hline $\begin{array}{c}\text { Macro- } \\
\text { environment }\end{array}$ & $\begin{array}{c}\text { Government } \\
\text { regulations, } \\
\text { Material purchases, } \\
\text { Upstream } \\
\text { programmes }\end{array}$ & $\begin{array}{l}\text { In projects A and B, clients were } \\
\text { responsible for procurement and } \\
\text { construction risks and the contractor was } \\
\text { responsible for engineering risks. } \\
\text { During projects A and B, clients started } \\
\text { demanding on-time execution and delivery } \\
\text { of the projects due to the country-level } \\
\text { economic growth. } \\
\text { During projects A, B and C, there was less } \\
\text { concern about completion from the client } \\
\text { side. }\end{array}$ & $\begin{array}{l}\text { During projects } \mathrm{D} \text { and } \mathrm{E} \text {, public clients were } \\
\text { under pressure from international competitors } \\
\text { and the rising private sector. } \\
\text { Project } \mathrm{C} \text {, as an interconnection project, } \\
\text { depended on a number of other petrochemical } \\
\text { plant development projects which were } \\
\text { managed and executed by several other clients } \\
\text { and main contractors. } \\
\text { In project } \mathrm{D} \text {, the steel price increased by } 40 \% \\
\text { after the award of the contract. } \\
\text { In project } \mathrm{E} \text {, project risks were shared between } \\
\text { the client and the contractor. }\end{array}$ & Static & Dynamic \\
\hline Uncertainty & $\begin{array}{l}\text { Project locations, } \\
\text { Technologies used, } \\
\text { Client needs }\end{array}$ & $\begin{array}{l}\text { Projects A and B also had a high level of } \\
\text { uncertainty, encouraging clients and main } \\
\text { contractors to transform their businesses } \\
\text { from transactional marketing. } \\
\text { Project A interconnected with a number of } \\
\text { other projects due to its location in a } \\
\text { petrochemical complex and its similar time } \\
\text { schedule with other projects. }\end{array}$ & $\begin{array}{l}\text { In project } C \text {, a new material was selected for } \\
\text { pipes during the project execution. } \\
\text { In project } C \text {, the capacity of utility systems } \\
\text { changed during the project execution. } \\
\text { In project } D \text {, the location of the flare system } \\
\text { was finalised during the project execution. }\end{array}$ & Low & High \\
\hline Communication & $\begin{array}{l}\text { Coordination } \\
\text { meetings, Inter- } \\
\text { organisational } \\
\text { meetings }\end{array}$ & $\begin{array}{l}\text { Project managers were point of contacts } \\
\text { between the contractor and the client in } \\
\text { projects } \mathrm{A} \text { and } \mathrm{B} \text {. }\end{array}$ & $\begin{array}{l}\text { In projects } \mathrm{C}, \mathrm{D} \text { and } \mathrm{E} \text {, engineering discipline } \\
\text { coordinators interacted with their client } \\
\text { counterparts to resolve issues with a threshold } \\
\text { of time, cost and scope. }\end{array}$ & Project level & $\begin{array}{l}\text { Multi-level } \\
\text { and } \\
\text { distributed }\end{array}$ \\
\hline $\begin{array}{l}\text { Extent of } \\
\text { contracts }\end{array}$ & $\begin{array}{l}\text { Main contracts, } \\
\text { Requests for } \\
\text { proposals }\end{array}$ & $\begin{array}{l}\text { Projects A and B were mainly engineering } \\
\text { and procurement services contracts where } \\
\text { procurement was done by the client and } \\
\text { the contractor was only responsible for }\end{array}$ & $\begin{array}{l}\text { Projects C, D and E were lump sum turn key } \\
\text { contracts where the contractor was responsible } \\
\text { for on time start up of plants with agreed } \\
\text { performance measures. }\end{array}$ & Engineering & Turnkey \\
\hline
\end{tabular}




\begin{tabular}{|c|c|c|c|c|c|}
\hline & & performing procurement activities. & & & \\
\hline $\begin{array}{l}\text { Interaction } \\
\text { mechanism }\end{array}$ & $\begin{array}{l}\text { Project structure, } \\
\text { Communication } \\
\text { procedures }\end{array}$ & $\begin{array}{l}\text { In projects } \mathrm{A} \text { and } \mathrm{C} \text { project specialists } \\
\text { were located at their functional role and } \\
\text { gave service to the project. In these } \\
\text { projects, the interactions between the } \\
\text { project and the specialists were managed } \\
\text { between project managers and functional } \\
\text { managers. }\end{array}$ & $\begin{array}{l}\text { In projects } \mathrm{B}, \mathrm{D} \text { and } \mathrm{E} \text {, the main contractor } \\
\text { project specialists were co-located along with } \\
\text { project management team and they directly } \\
\text { interacted with the project management team. } \\
\text { Furthermore, co-location of client team or their } \\
\text { managing consultants were negotiated and } \\
\text { granted to facilitate direct interactions among } \\
\text { the main contractors and client teams. }\end{array}$ & Formal & Co-location \\
\hline Risk & $\begin{array}{l}\text { Main contracts, } \\
\text { Contract } \\
\text { negotiations, } \\
\text { Procurement } \\
\text { contracts }\end{array}$ & $\begin{array}{l}\text { Clients took the most financial risks in } \\
\text { projects A and B. In particular, } \\
\text { procurement commercial activities } \\
\text { accounting for around } 70 \% \text { of the project } \\
\text { costs were performed by clients. }\end{array}$ & $\begin{array}{l}\text { In projects } \mathrm{C}, \mathrm{D} \text { and } \mathrm{E}, \text { project risks were } \\
\text { shared between clients and the main contractor. } \\
\text { Although in these projects the main contractor } \\
\text { was responsible for all project activities, they } \\
\text { were liable to the client for up to } 10 \% \text { of the } \\
\text { project costs. Therefore, clients worked closely } \\
\text { with the main contractor (through a third party } \\
\text { managing consultants or their own teams) to } \\
\text { make sure project risks were properly managed. }\end{array}$ & Transferred & Shared \\
\hline Objectives & $\begin{array}{c}\text { Project charters, } \\
\text { Management } \\
\text { decisions, Incentive } \\
\text { system }\end{array}$ & $\begin{array}{l}\text { In all projects time, cost and scope were } \\
\text { the main objectives for the main } \\
\text { contractor. However, these objectives were } \\
\text { not directly linked to the clients project } \\
\text { objectives in projects A and B. For } \\
\text { instance, in projects A and B the client } \\
\text { could improve project costs dramatically } \\
\text { with some extra costs on engineering } \\
\text { activities. However, the main contractor, } \\
\text { being responsible for engineering } \\
\text { activities, was cautious regarding } \\
\text { engineering costs. }\end{array}$ & $\begin{array}{l}\text { In projects C, D and E, the main objective for } \\
\text { both the main contractor and clients was to start } \\
\text { up the industrial plant with an acceptable } \\
\text { performance and within an acceptable time } \\
\text { scale. Therefore, cost and time were second } \\
\text { order objectives in the main contractor's } \\
\text { decision-making processes and the first order } \\
\text { objective was to solve problems impeding the } \\
\text { achievement of the main goal. }\end{array}$ & Cost and time & $\begin{array}{l}\text { Problem } \\
\text { solving }\end{array}$ \\
\hline Services & $\begin{array}{l}\text { Project organisation } \\
\text { structure, Project } \\
\text { activity lists }\end{array}$ & $\begin{array}{l}\text { Projects A and B mainly focused on } \\
\text { engineering activities. In these projects, } \\
\text { procurement services only included } \\
\text { searching for the suppliers and technical } \\
\text { evaluation of their bids. }\end{array}$ & $\begin{array}{l}\text { Services were expanded in projects D and E and } \\
\text { partially expanded in project C. In particular, } \\
\text { commercial procurement services, project } \\
\text { financing and construction management were } \\
\text { added to the main contractor services in projects } \\
\text { D and E. }\end{array}$ & Specialised & Expanded \\
\hline
\end{tabular}




\begin{tabular}{|c|c|c|c|c|c|}
\hline Focus of skills & $\begin{array}{c}\text { Promotions, } \\
\text { Position placements }\end{array}$ & $\begin{array}{l}\text { In projects } \mathrm{A}, \mathrm{B} \text { and to some extent } \mathrm{C} \text {, } \\
\text { engineering design skills were considered } \\
\text { as a core capability for the project team. In } \\
\text { these projects, project teams were } \\
\text { incentivised based on their capability to } \\
\text { resolve technical challenges in the project. }\end{array}$ & $\begin{array}{l}\text { In projects } \mathrm{D}, \mathrm{E} \text { and to some extent } \mathrm{C} \text {, } \\
\text { interpersonal skills were important in addition } \\
\text { to technical capabilities. In these projects, } \\
\text { engineering team leaders were those who were } \\
\text { able to interact with project stakeholders } \\
\text { considering the political and relational } \\
\text { mechanisms in the project. }\end{array}$ & Technical & $\begin{array}{l}\text { Interpersona } \\
1\end{array}$ \\
\hline Motivation & $\begin{array}{l}\text { Personal } \\
\text { achievements, } \\
\text { Employees' time } \\
\text { allocation for } \\
\text { activities }\end{array}$ & $\begin{array}{l}\text { In project A, some of the project team } \\
\text { members spent only a small portion of } \\
\text { their time on the project. Therefore, there } \\
\text { was less association between project } \\
\text { success and individual members' } \\
\text { successes. }\end{array}$ & $\begin{array}{l}\text { In projects } \mathrm{D} \text { and } \mathrm{E} \text {, and to some extent } \mathrm{C} \text { and } \\
\mathrm{B} \text {, the project success was strongly associated } \\
\text { with the project team success. In particular, in } \\
\text { these projects the main portion of the project } \\
\text { team's time was allocated to the project. }\end{array}$ & Financial & Self-interest \\
\hline Employees & $\begin{array}{l}\text { Management } \\
\text { practices, } \\
\text { Management } \\
\text { control system }\end{array}$ & $\begin{array}{l}\text { In project A, the project manager was } \\
\text { responsible for project costs and the } \\
\text { project team had less authority to change } \\
\text { the processes, scope and technical } \\
\text { elements of the project. In this project, and } \\
\text { to some extent in projects B and C, the } \\
\text { project manager was engaged in and made } \\
\text { most of the project decisions. }\end{array}$ & $\begin{array}{l}\text { In projects D and } \mathrm{E} \text {, and to some extent } \mathrm{C} \text { and } \\
\mathrm{B} \text {, project team were able to suggest and } \\
\text { implement innovative processes and negotiate } \\
\text { with project stakeholders such as clients to gain } \\
\text { their acceptance for appropriate changes. In } \\
\text { project } \mathrm{D} \text { and } \mathrm{E} \text {, the project teams were } \\
\text { empowered to make decisions within a time and } \\
\text { cost threshold. }\end{array}$ & Controlled & Empowered \\
\hline $\begin{array}{l}\text { Performance } \\
\text { metrics }\end{array}$ & $\begin{array}{l}\text { Client contracts, } \\
\text { employee } \\
\text { performance } \\
\text { appraisal }\end{array}$ & $\begin{array}{l}\text { In projects } \mathrm{A}, \mathrm{B} \text { and } \mathrm{C} \text {, the main contractor } \\
\text { managed performance based on } \\
\text { engineering man-hours. There were } \\
\text { specific man-hour metrics for preparing } \\
\text { different range of engineering documents. } \\
\text { A quality management system was also in } \\
\text { place to make sure that documents } \\
\text { generated were acceptable in quality. }\end{array}$ & $\begin{array}{l}\text { In projects D and E, performances were } \\
\text { managed based on the metrics associated with } \\
\text { the whole-life cost of the project and project } \\
\text { outcomes. In particular, project teams were } \\
\text { appraised according to their overall impact on } \\
\text { project success. This strategy was contradictory } \\
\text { to the existing processes in the organisation. } \\
\text { Therefore, the metrics used in these projects } \\
\text { included a combination of old metrics and a } \\
\text { new qualitative evaluation of performances by } \\
\text { project managers. }\end{array}$ & $\begin{array}{l}\text { Man-hours, } \\
\text { Material costs }\end{array}$ & $\begin{array}{l}\text { Outcome, } \\
\text { Whole-life } \\
\text { cost }\end{array}$ \\
\hline
\end{tabular}




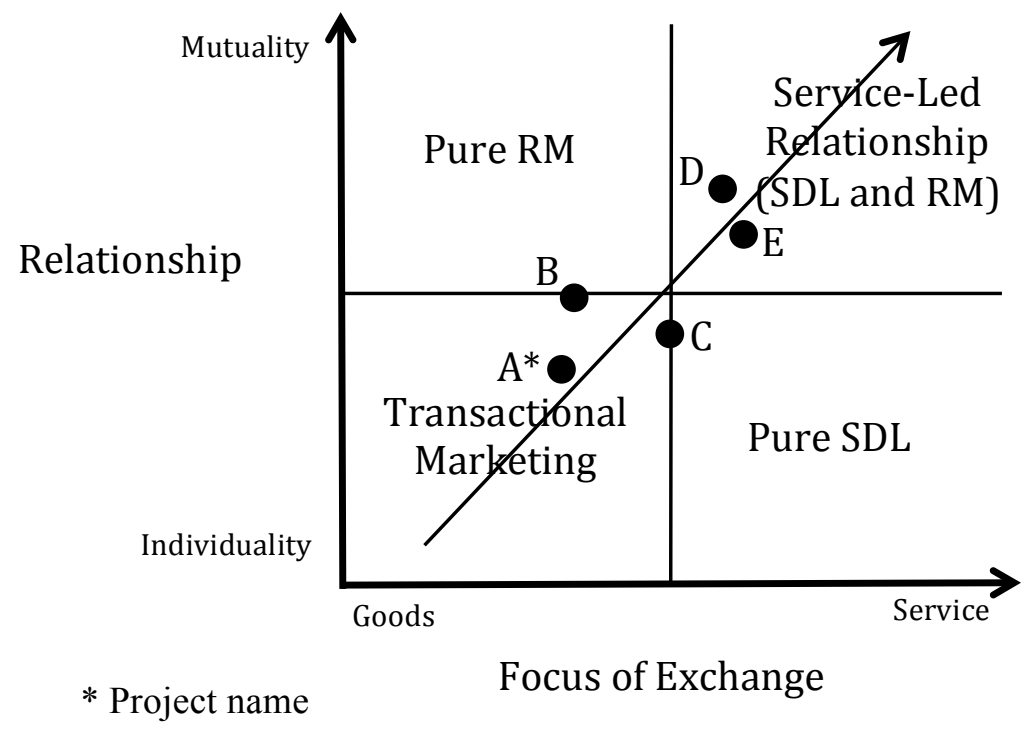

Figure 1, Four Marketing Views of Customer-Provider Interaction 